\title{
Erratum to: Seeking Success in E-Business
}

Kim Viborg Andersen ${ }^{1}$, Steve Elliot ${ }^{2}$, Paula Swatman ${ }^{3}$, Eileen Trauth ${ }^{5}$, and Niels Bjørn-Andersen ${ }^{1}$

1 Copenhagen Business School, Denmark

2 University of Sydney, Australia

3 University of Koblenz-Landau, Germany and Deakin University, Australia

${ }^{4}$ Pennsylvania State University, USA

\section{Erratum to:}

\section{K.V. Andersen et al. (Eds.)}

Seeking Success in E-Business

DOI: $10.1007 / 978-0-387-35692-1$

The book was inadvertently published with an incorrect name of the copyright holder. The name of the copyright holder for this book is: (c) IFIP International Federation for Information Processing. The book has been updated with the changes. 